Amiruddin

\title{
EFEKTIVITAS MGMP DI MADRASAH ALIYAH NEGERIMAMUJU PROVINSI SULAWESI BARAT
}

\section{Oleh: Amiruddin."}

\begin{abstract}
The research aims to describe the effectiveness of MGMP in MAN Mamuju, west Sulawesi province. Result shows that generally the implementation of MGMP in MAN Mamuju is quite effective. However, the teachers thought that it lacked government support and result in its low quality. MGMP is an institution where the teacher can discuss the learning system on the courses in school. To improve the quality of the discussion which can increase the capability of the teacher on learning and syllabus development method, the support of government and other institution is required.
\end{abstract}

Key Word: effectiveness, MGMP (teacher discussion on course)

\section{PENDAHULUAN}

$\mathrm{M}$

adrasah merupakan lembaga pendidikan agama yang dalam sejarah sangat konsisten dalam melahirkan intelektual-intelektual bermoral karena nilai-nilai keagamaan sangat subur dalam sistem pendidikan yang juga media perjuangan untuk mempertahankan ajaran-ajaran Islam secara fundamental (mendasar). Seharusnya proses pembelajaran dan pendidikan yang dianut sistem madrasah perlu dilestarikan dan dikembangkan dengan memberikan porsi perhatian yang seimbang mengingat peranannya yang sangat krusial.

Madrasah adalah suatu lembaga pendidikan yang tidak dapat digantikan dengan lembaga-lembaga lain, sebab awal kelahiran madrasah merupakan suatu upaya menjawab kebutuhan masyarakat mengenai pendidikan terutama masalah agama yang mempunyai visi, misi dan karakteristik yang sangat khas di dalam masyarakat, diperlukan upaya peningkatan mutu pendidikan.

Penulis adalah Peneliti Balai Penelitian dan Pengembangan Agama Makassar. 
Lembaga pendidikan Islam ini menawarkan konsep pendidikan terhadap pemahaman tentang ajaran Islam yang mewajibkan semua umatnya berakhlak mulia. Ketika peranan agama dimarginalkan, bisa dipastikan implikasi (dampak) negatifnya akan menjadi "wabah" yang merusak sendi-sendi kehidupan sosial di tengah-tengah masyarakat sebagai konsekuensi tidak kuatnya atau lemahnya peranan madrasah sehingga terjadi dekadensi (keterpurukan) moral bangsa kita, karena dipimpin dan di huni oleh orang-orang yang tidak berakhlak mulia. Karena itu, di dalam pemahaman literature Islam disebutkan bahwa adab (akhlak yang baik) kedudukannya lebih ketimbang ilmu.

Oleh karena itu, kepedulian terhadap peningkatan sumber daya manusia melalui lembaga pendidikan merupakan modal besar dalam investasi pembangunan bangsa, dan pada level mikro melalui lembaga pendidikan berperan sebagai muara sentral dalam rangka mengantisipasi merosotnya kualitas sumber daya manusia yang diarahkan pada peningkatan kualitas lulusan yang mempunyai kepercayaan diri yang kuat, produktif, dan mampu bersaing, dan guru dapat membawa peserta didik agar dapat memahami agama sebagai pedoman hidup yang dapat mengatur aspek kehidupan manusia. Pendidikan yang paling tepat adalah madrasah yang mempunyai ciri khas Agama Islam yang diselenggarakan oleh Departemen Agama sebagaimana Surat Keputusan Menteri No. 0489/U/1992.

Upaya peningkatan mutu madrasah harus menjalani perubahan sebagai upaya mengejar ketertinggalan dengan sekolah umum. Dalam hal ini guru adalah sebagai salah satu unsur pokok dalam pengelolaan proses pendidikan di sekolah yang menjadi titik sentral peningkatan mutu pendidikan. Mengenai hal tersebut, pendidikan harus dikembangkan secara dinamik sesuai dengan tantangan dan perubahan zaman, seiring dengan meningkatnya perkembangan pengetahuan dan teknologi agar pembelajaran selalu aktual dan signifikan. Dengan adanya peningkatan mutu pendidikan madrasah, lahirlah kesejajaran madrasah khususnya madrasah aliyah dengan sekolah umum, sebagaimana disebutkan pada PP No. 29/1990 tentang pendidikan menengah, dengan merevisi kurikulum menjadi sekolah umum plus.

Pengakuan tersebut adalah suatu nilai tambah yang diberikan kepada pendidikan madrasah sekaligus sebagai tantangan besar, mengingat pengintegrasian pendidikan umum dan agama harus dikembangkan secara seimbang. Kesadaran dan keinginan meningkatkan kualitas guru sebagai tenaga kependidikan perlu adanya pengembangan kesejawatan yang memerlukan wadah 
yaitu kelembagaan yang bersifat non struktural yang lebih bersifat formal. Bentuk kegiatan di dalamnya merupakan kelompok dimana antar anggota saling berdiskusi dan memberi masukan.

Bentuk kegiatan tersebut adalah melalui Musyawarah Guru Mata Pelajaran (MGMP) sebagai salah satu sarana pengembangan karir guru. Dengan harapan bahwa kegiatan ini mampu meningkatkan gairah inovatif, kreatifitas dan keterampilan para guru, serta dapat menjembatani para guru untuk melakukan konsultasi dalam menyelesaikan masalah, baik sebagai forum maupun pembinaan kepada guru yang bermasalah.

MGMP sebagai wadah pembinaan profesionalisme guru diharapkan mampu mengembangkan wawasan, pengetahuan dan keterampilan mengajar guru guna menemukan masalah-masalah yang memerlukan kajian cermat dan sistematis, misalnya masalah rendahnya nilai Ujian Akhir Nasional (UAN), bagaimana memotivasi cara belajar siswa, bagaimana menciptakan kondisi belajar yang baik, dan bimbingan guru mata pelajaran dalam meningkatkan kecakapan akademik siswa.Salah satu upaya untuk meningkatkan kompetensi guru madrasah dituntut untuk meningkatkan mutu dengan mengaktifkan Musyawarah Guru Mata Pelajaran (MGMP).

Secara bertahap, berbagai upaya untuk meningkatkan kualitas kompetensi • guru madrasah dan tenaga kependidikan lainnya, telah dilakukan oleh Departemen Agama melalui berbagai pendidikan dan pelatihan, baik melalui kerjasama dengan berbagai lembaga pendidikan maupun secara mandiri oleh Pusdiklat dan Balai Diklat di daerah.

Hasil kediklatan memperlihatkan bahwa program kediklatan selama ini belum memberikan dampak yang signifikan terhadap peningkatan kualitas madrasah. Hasil penelitian evaluasi yang dilakukan Badan Litbang dan Diklat bekerjasama dengan CERDEV UIN Syarif Hidayatullah Jakarta tahun 2006, menyatakan bahwa Diklat GPAI SLTP dan Dosen agam belum memenuhi harapan, meskipun dari sisi teknis dinilai cukup memuaskan. Temuan lain menyebutkan diklat-diklat tersebut belum disusun berdasakan analisa kebutuhan, serta dirancang secara terpadu dengan melibatkan berbagai komponen terkait.

Selain itu, temuan penelitian Puslitbang Pendidikan dan Keagamaan Badan Litbang dan Diklat tahun 2005, berkaitan dengan penyelenggaraan Diklat GPAI SD/SLTP, antara lain: Penyusunan kurikulum kurang memperhatikan kebutuhan- 


\section{Amiruddin}

kebutuhan GPAI dan dalam penerapannya kurang mengapresiasikan perkembangan dunia pendidikan dan perkembangan ilmu pengetahuan dan teknologi. ${ }^{2}$

Sementara itu, salah satu organisasi yang muncul dalam lembaga sekolah sebagai upaya untuk mengembangkan dan meningkatkan kualitas pengajaran adalah MGMP yang sama untuk saling berdiskusi dan bertukar pikiran seabagai wahana pengembangan pengetahuan. Posisi MGMP menjadi penting dalam sekolah sebagai wadah bagi guru untuk merumuskanmodel pembelajaran yang paling sesuai dengan kondisi terkini para siswa. Posisi penting ini mengharuskan MGMP diisi oleh tenaga-tenaga pengajar yang memiliki kualifikasi yang baik.

Berdasarkan latar belakang masalah tersebut maka secara operasional dapat dirumuskan masalah pokok dalam penelitian ini sebagai berikut: Bagaimana kegiatan Musyawarah Guru Mata Pelajaran (MGMP) tersebut dalam meningkatkan mutu pendidikan di Madrasah Aliyah Negeri Mamuju Provinsi Sulawesi Barat.

\section{TINJAUAN PUSTAKA}

\section{Tentang Musyawarah Guru Mata Pelajaran (MGMP)}

Musyawarah Guru Mata Pelajaran (MGMP) adalah suatu lembaga mandiri yang tidak mempunyai struktur organisasi yang, tetapi merupakan wadah berkumpulnya guru mata pelajaran sejenis, berperan melaksanakan pengembangan wawasan pengetahuan dan kompetensi guru sehingga memiliki dedikasi yang tinggi. Di samping itu dalam wadah MGMP juga dapat melakukan refleksi diri ke arah pembentukan profil guru yang professional.

Salah satu program MGMP adalah pelatihan. Sebagaimana Peraturan Pemerintah RI No. 101 tahun 2001 tentang Pendidikan dan Pelatihan Jabatan Pegawai Negeri Sipil Bab II, Pasal 2 Tujuan Diklat Aparatur meliputi:

1. Meningkatkan pengetahuan, keterampilan untuk dapat melaksanakan secara profesionalisme

2. Menciptakan aparatur yang mampu berperan sebagai pembaharu

3. Memantapkan sikap dan semangat pengabdian

4. Menciptakan kesamaan dan dinamika pola pikir dalam melaksanakan tugas. 
Sehubungan hal tersebut, salah satu program pembinaan guru melalui kegiatan MGMP merupakan elemen penting dalam peningkatan kualitas dan kuantitas pembelajaran dikelas. Pembinaan guru dalam kegiatan MGMP mengarah kepada upaya peningkatan kepercayaan diri dalam mengelola proses belajar mengajar dan pendalam materi yang dikelolah dari guru oleh guru dan untuk guru.

\section{Profesionalisme dan Kompetensi Guru Sebagai Tlijuan MGMP}

Guru adalah jabatan profesional yang memerlukan berbagai keahlian khusus dalam hal ini kompetensi. Kompetensi dapat diberikan makna sebagai orang yang memiliki kemampuan, kekuasan, kewenangan, keterampilan, pengetahuan yang diperlukan untuk melakukan sesuatu, Suhertian dkk memberikan pengertian bahwa kompetensi berupa kemampuan melaksanakan sesuai yang diperoleh melalui pendidikan dan pelatihan. ${ }^{3}$ Selanjutnya Djamarah memberikan makna, kompetensi guru adalah pemilikan pengetahuan keguruan, dan pemilikian keterampilan serta kemampuan sebagai guru dalam melaksanakan tugasnya. ${ }^{4}$ Selain itu menurut Brofty yang dimaksud dengan kompetensi guru adalah kempuan seorang guru dalam melaksanakan kewajiban-kewajibannya secara bertanggung jawab dan layak.

Kompetensi adalah kemampuan atau kecakapan guru. Menurut Mulyasa kompetensi guru merupakan gambaran kualitatif tentang hakekat prilaku guru yang penuh arti. ${ }^{6}$

Dari uraian tersebut, maka yang dimaksud dengan kompetensi guru adalah senantiasa bebas berimprovisasi sesuai kondisi untuk menggunakan multi metode dan multi media dan tidak terpaku pada stu jenis metode mengajar saja. Selain itu komitmen dan motivasi guru di madrasah negeri yang dilandasi kemauan untuk maju bersama sangat penting untuk penin gkatan kualitas. Kualitas guru di madrasah dipengaruhi oleh motivasi yang tinggi dan dapat ditingkatkan melalui pelatihan termasuk didalam Musyawarah Guru Mata Pelajaran (MGMP) antar teman sejawat atau antar sekolah setingkat MAN dan sekolah umum guna mengembangkan kemampuan secara kompetitif.

Kompetensi yang harus dimiliki oleh seorang guru dalam jenjang pendidikan apapun yaitu, kompetensi- kompetensi professional, kompetensi kepribadian, dan kompetensi kemasyarakatan. Sedangkan Suharsimi Arikunto kompetensi guru dibagi menjadi tiga yakni, (1) kompetensi individu, (2) kompetensi profes- 
sional, dan (3) kompetensi sosial. Suhertian dkk, juga membagi menjadi tiga yakni (1) kompetensi pribadi, (2) kompetensi profesional, dan (3) kompetensi kemasyarakatan. ${ }^{8}$

Menurut Suhertian, kompetensi professional guru adalah kemampuan dalam penguasaan akademik yang diajarkan sekaligus kemampuan mengajarnya.' Sedangkan kompetensi individu menurut Arikunto adalah kemampuan guru untuk memiliki sikap dan kepribadian yang mantap dan patut diteladani. ${ }^{10}$ Adapun kompetensi sosial menurut Arikunto adalah kemampuan guru berakomodasi dengan para siswa, guru, kepala sekolah, pegawai, tata usaha, anggota masyarakat dilingkungannya." Sedangkan Sukmadinata memaknai kompetensi sosial sebagai kemampuan menyesuaikan diri dangan tuntunan dan lingkungan sekitar. $^{12}$

\section{HASIL DAN PEMBAHASAN}

\section{Program Kerja dan Mekanisme Kerja MGMP MAN Mamuju}

Kegiatan yang dilakukan oleh Musyawarah Guru Mata Pelajaran (MGMP) dibeberapa rumpun MGMP yang ada di Madarasah Aliyah Negeri (MAN) Mamuju Provinsi Sulawesi Barat seperti MGMP rumpun PAI, MGMP rumpun MIPA, MGMP rumpun IPS dan MGMP Bahasa Inggris masih sangat kurang intensitas kegiatan yang dilakukannya, hal ini disebabkan karena seluruh MGMP yang ada di Madrasah Aliyah Negeri (MAN Mamuju) baru terbentuk pada pada pertengahan tahun 2007.

Namun kegiatan yang dilakukan oleh beberapa MGMP di MAN Mamuju walaupun proses pembentukkan masih baru terbentuk ini telah memberikan kontribusi dan pencerahan kepada guru-guru yang tergabung dalam MGMP baik dalam rumpun MIPA, PAI, IPS maupun MGMP Bahasa Inggris yang masuk dalam Lingkup KKM se-Kabupaten Mamuju. Banyak guru-guru yang telah merasakan manfaat dari keikutsertaan mereka dalam kegiatan MGMP MAN Mamuju. Kegiatan yang selama ini diikuti oleh anggota MGMP adalah meliputi teknik pembuatan perangkat pembelajaran yang mencakup tata cara pembuatan RPP, silabus, pendalaman materi, serta pembuatan LKS dan lain sebagainya.

Sedangkan tempat untuk melaksanakan kegiatan yang dilakukan oleh setiap rumpun MGMP MAN Mamuju, seluruhnya berpusat pada sekertariat MGMP yang ada di lokasi Madrasah Aliyah Negeri Mamuju, dan intensitas pertemuan bervariasi antara 1 sampai dengan 3 kali pertemuan dalam setiap semester 
dengan lama pertemuan diatas satu jam yang dihadiri oleh para pengurus dan anggota MGMP Madrasah Aliyah Negeri Mamuju.

Setiap kegiatan yang dilakukan oleh masing-masing rumpun MGMP yang ada di MAN Mamuju biasanya anggota MGMP tersebut tidak seluruhnya bisa hadir, hal ini disebabkan oleh beberapa kendala yang memungkinkan anggota tidak bisa menghadiri pertemuan tersebut. Kendala-kendala yang dimaksud seperti, tempat pertemuan yang dianggap jauh dari tempat tinggal, biaya transportasi ke tempat pertemuan, kurangnya informasi yang diterima oleh anggota, jadwal pertemuan bertepatan dengan waktu mengajar, serta biasanya pertemuan dilakukan di luar jam kerja.

Intensitas kegiatan MGMP belum maksimal sehingga hasil yang dirasakan oleh anggota MGMP tentunya belum maksimal pula, tapi pihak pengurus MGMP berusaha untuk selalu berdiskusi dengan para anggota disela-sela kegiatan belajar mengajar. Mereka berpendapat bahwa kegiatan MGMP ini selamanya akan diintensifkan walaupun sudah tidak ada dana yang dikucurkan oleh pihak pusat baik Departemen Agama maupun dari Diknas Pendidikan, tapi mereka sudah berkomitmen untuk melakukan kegiatan diluar kegiatan resmi, hal ini dimungkinkan karena MGMP ini hanya bersifat intern dalam lingkup Madrasah Aliyah Negeri (MAN Mamuju) saja, sehingga pertemuan diantara anggota MGMP selalu siap kapan dan dimanapun.

Hal yang menjadi pendorong minat para anggota MGMP dalam menghadiri dan mengaktifkan kegiatan-kegiatan MGMP di setiap rumpun baik yang sudah terprogram maupun yang dilaksanakan secara spontanitas dikarenakan adanya motivasi dari Kepala Madrasah Aliyah Negeri yang senantiasa mengarahkan dan memberikan dukungan baik moril maupun material atas segala kegiatan yang akan dilakukan oleh setiap rumpun MGMP yang ada di Madrasah Aliyah Negeri Mamuju. Di samping itu, setiap agenda pertemuan MGMP tersebut sangat sesuai dengan peningkatan profesionalisme guru, karena didukung oleh para narasumber yang memberi mated dalam kegiatan atau pertemuan ahli di bidangnya yang mendiskusikan secara intensif tentang pengalaman-pengalaman mengajar yang bisa diadopsi oleh para guru yang tergabung dalam keanggotaan MGMP.

Biasanya hal yang paling sering diperbincangkan atau didiskusikan oleh para anggota MGMP adalah bagaimana meningkatkan profesionalisme para anggota dan menumbuhkan semangat pengabdian terhadap tanggung jawab sebagai seorang guru agar anak yang didiknya dapat menghasil dan berhasil guna dimasa yang akan datang. 
Amiruddin

Data penelitian telah menemukan tentang jenis kegiatan yang telah di laksanakan oleh beberapa rumpun MGMP yang ada di Madrasah Aliyah Negeri (MAN Mamuju) Provinsi Sulawesi Barat. Dan untuk kejelasannya akan dipaparkan dibawah ini:

\section{MGMP Bahasa Inggris}

MGMP Bahasa Inggris Madrasah Aliyah Se Kabupaten Mamuju telah melaksanakan beberapa kali kegiatan berkala yang sekaitan dengan rencana dan penyelenggaraan pendidikan, yang dihadiri oleh seluruh anggota MGMP Bahasa Inggris se-Madrasah Aliyah. Kegiatan-kegiatan berkala yang dimaksud adalah sebagai berikut:

\section{a. Persiapan Ujian Nasional}

Kegiatan ini adalah merupakan kegiatan yang pertama kali dilakukan oleh MGMP Bahasa Inggris adalah berupa "Persiapan Ujian Nasional" dengan sub kegiatan tentang pembahasan soal-soal Ujian Nasional tahun 2003/2004,2004/ $2005,2005 / 2006$, pembuatan kisi-kisi soal prediksi UN tahun 2007, dan pembuatan soal-soal prediksi berstandar UN tahun 2007.

Kegiatan ini dilaksanakan selama tiga (3) hari mulai dari hari Kamis sampai dengan hari Sabtu tanggal 15 s/d 17 Pebruari 2007 yang bertempat di gedung pertemuan MAN Mamuju Jl. Soekarno Hatta (Poros Baru) Kab. Mamuju.

Tujuan yang ingin dicapai dengan dilaksanakannya kegiatan ini agar supaya guruguru yang terhimpun dalam MGMP Bahasa Inggris ini dapat atau mampu membuat kisi-kisi soal prediksi Ujian Nasional (UN) tahun 2007, serta diharapkan pula mampu membuat soal-soal prediksi yang berstandar Ujian Nasional (UN). Di samping itu dengan adanya kegiatan pelatihan persiapan Ujian Nasional diharapkan guru-guru dapat menjawab soal-soal Ujian Nasional (UN) tahun 2004,2005, dan 2006.

\section{b. Sosialisasi KTSP dan Workshop Pembuatan Perangkat Pembelajaran}

Kegiatan ini adalah kelanjutan dari program yang telah dicanangkan oleh MGPM Bahasa Inggris Madrasah Aliyah dan merupakan kegiatan berkala tahap kedua, dengan mengetengahkan materi kegiatan berupa:

- $\quad$ Sosialisasi KTSP dan Presentasi Kurikulum MAN Mamuju

- Teknik Pembuatan Silabus dan Rencana Pelaksanaan Pembelajaran (RPP)

- $\quad$ Sistem Penilaian Berbasis Kelas. 
Kegiatan ini dilaksanakan selama tiga (3) hari mulai dari hari Jum'at sampai dengan hari Minggu, tanggal 09 s/d 11 Maret 2007 yang bertempat di gedung pertemuan MAN Mamuju Jl. Soekarno Hatta (Poros Baru) Kab. Mamuju.

Maksud dan tujuan dilaksanakannya kegiatan ini tentunya agar guru-guru dapat memperoleh wawasan tentang KTSP (Permen 22,23, dan 24), diharapkan guru dapat membuat draft Perangkat Pembelajaran seperti; Silabus, RPP dan Sistem Penilaian, serta diarahkan agar guru mampu membuat Finalisasi Perangkat Pembelajaran seperti: Silabus, RPP dan Sistem Penilaian.

\section{c. Sosialisasi/Uji Coba Sertifikasi Profesi Guru dan Pembuatan Soal- Soal Olimpiade bahasa Inggris}

Musyawarah Guru Mata Pelajaran (MGMP) Bahasa Inggris Madrasah Aliyah se- Kabupaten Mamuju Melakukan kegiatan dengan tema "Sosialisasi/ Uji Coba Sertifikasi Profesi Guru dan Pembuatan Soal-Soal Olimpiade Bahasa Inggris", dengan materi kegiatan berupa: sosialisasi sertifikasi guru, uji coba soal-soal latihan sertifikasi, dan pembuatan soal-soal olimpiade Bahasa Inggris tingkat madrasah aliyah.

Kegiatan ini dilaksanakan selama tiga (3) hari mulai dari hari Kamis sampai dengan hari Sabtu, tanggal 24 s/d 26 Mei 2007 yang bertempat di gedung pertemuan MAN Mamuju Jl. Soekarno Hatta (Poros Baru) Kabupaten Mamuju.

Maksud dan tujuan dilaksanakannya kegiatan ini adalah untuk menambah wawasan guru-guru agar dapat memperoleh pengetahuan tentang Sertifikasi Profesi Guru (UU No. 14 Tahun 2005), agar guru dapat lulus dalam ujicoba sertifikasi guru, serta guru diharapkan dapat membuat kisi-kisi dan soal-soal olimpiade Bahasa Inggris.

\section{d. Pembuatan LKS dan Pendalaman Materi Bahasa Inggris}

Kegiatan ini dilaksanakan pada bulan Desember 2007, tepatnya pada tanggal 14 s/d 16 Desember 2007, yang merupakan kegiatan terakhir dari beberapa rangkaian kegiatan yang dilakukan oleh MGMP Bahasa Inggris Madrasah Aliyah Se-Kabupaten Mamuju dengan materi kegiatan berupa:

- Teknik Pembuatan LKS

- Pembuatan Kerangka Penulisan

- Pembuatan Draft LKS

- Pembuatan Finalisasi LKS dan

Pendalaman Materi (Listening, Speaking, Reading, and Writing) Bahasa Inggris Madrasah Aliyah. 
Amiruddin

\section{MGMP Rumpun PAI}

Semenjak berdirinya MGMP-PAI pada tahun 2007 baru satu kali melakukan kegiatan dalam bentuk workshop tentang "Pembuatan Perangkat Pembelajaran" berupa program tahunan, program semester, analisis hari efektif, pembuatan silabus, RPP, KKM/SKBM, dokumen penilaian untuk semua mata pelajaran pada rumpun Pendidikan Agama Islam (PAI) yang terdiri dari mata pelajaran Qur'an Hadits, Aqidah Akhlak, Fiqih, SKI, dan muatan lokal (baca tulis Alquran). Kegiatan ini dilaksanakan pada bulan Desember 2007, tepatnya pada tanggal $21 \mathrm{~s} / \mathrm{d} 22$ Desember 2007 yang bertempat di ruang pertemuan MAN Mamuju, Jalan Soekamo Hatta Kabupaten Mamuju.

Kegiatan ini cukup efektif bagi guru rumpun PAI karena dapat membantu mereka dalam melengkapi administrasi wajib guru khususnya pada Mata Pelajaran rumpun PAI, juga memudahkan guru dalam melaksanakan kegiatan pembelajaran, guru dapat mengoptimalkan hasil pembelajaran karena mengaju pada perangkat pembelajaran, serta dalam kegiatan pembelajaran dapat berjalan efektif dan efesien.

\section{MGMP Rumpun IPS}

Jenis kegiatan yang pernah dilakukan oleh MGMP Rumpun IPS Madrsah Aliyah Negeri Mamuju adalah "Workshop Pembuatan Perangkat Pem-belajaran". perangkat pembelajaran yang dibahas pada kegiatan ini berupa, program tahunan, program semester, analisis hari efektif, pembuatan silabus, RPP, KKM/SKBM, dokumen penilaian untuk semua mata pelajaran pada rumpun Ilmu Pengetahuan Sosial (IPS) Madrasah Aliyah yang terdiri dari Mata Pelajaran Ekonomi, Geografi, Sosiolog, Sejarah, dan PKN. Kegiatan ini dilaksanakan pada bulan Desember 2007, tepatnya pada tanggal 14 s/d 16 Desember 2007 yang bertempat di ruang Pertemuan MAN Mamuju, Jalan Soekamo Hatta Kabupaten Mamuju.

Kegiatan ini cukup efektif bagi guru rumpun IPS karena dapat membantu guru Rumpun IPS dalam melengkapi administrasi wajib guru khususnya pada Mata Pelajaran Rumpun IPS, memudahkan guru dalam melaksanakan kegiatan pembelajaran, guru dapat mengoptimalkan hasil pembelajaran karena mengaju pada perangkat pembelajaran, serta dalam kegiatan pembelajaran dapat berjalan efektif dan efesien.

\section{MGMP Rumpun MIPA}

Sama halnya MGMP yang lainnya, kegiatan yang dilakukan baru satu kali dalam bentuk workshop tentang "Pembuatan Perangkat Pembelajaran " berupa 
program tahunan, program semester, analisis hari efektif, pembuatan silabus, RPP, KKM/SKBM, dokumen penilaian untuk semua mata pelajaran pada rumpun matematika dan ilmu pengetahuan alam (MIPA) yang terdiri dari mata pelajaran matematika, biologi, fisika, dan kimia. Kegiatan ini dilaksanakan pada bulan Desember 2007, tepatnya pada tanggal 07 s/d 09 Desember 2007.

Tempat pelaksanaan kegiatan MGMP diadakan di ruangan pertemuan MAN Mamuju jalan Soekarno Hatta Kabupaten Mamuju. Kegiatan ini cukup efektif bagi guru rumpun MIPA karena dapat membantu guru Rumpun MIPA dalam melengkapi administrasi wajib guru khususnya pada Mata Pelajaran Rumpun MTPA, memudahkan guru dalam melaksanakan kegiatan pembelajaran, guru dapat mengoptimalkan hasil pembelajaran karena mengaju pada perangkat pembelajaran, serta dalam kegiatan pembelajaran dapat berjalan efektif dan efesien.

\section{Respon Guru Terhadap Kegiatan MGMP MAN Mamuju}

\section{Minat}

Minat guru untuk aktif dalam kegiatan MGMP menunjukkan antusiasme yang cukup tinggi, karena terhitung sebagai kredit poin dalam penilaian untuk sertifikasi guru, sehingga kegiatan MGMP perlu dioptimalkan baik untuk rumpun agama maupun bidang studi umum demi untuk meningkatkan SDM dan kompetensi guru. Secara tidak langsung guru sudah termotivasi untuk menggiatkan MGMP karena ada nilai plus yang didapatkan dari MGMP itu, di samping SDM yang dimiliki akan semakin meningkat karena berkumpulnya beberapa guru dalam satu mata pelajaran yang memungkinkan untuk saling sharing pengalaman dan sebagainya juga untuk kredit poin dalam sertifikasi guru.

Di samping itu MGMP adalah merupakan salah satu media untuk saling bertemunya guru-guru yang satu profesi sehingga besar kemungkinan untuk selalu bertukar pikiran, sharing dan bekerja sama dalam memberikan informasi tentang proses belajar mengajar, hal ini pula yang membuat guru sangat berminat dan merespon segala aktifitas yang dilaksanakan oleh MGMP tersebut.

\section{Motivasi}

Program yang ditawarkan oleh MGMP yang menuntut peningkatan profesionalisme dalam kaitannya dengan proses belajar mengajar yang membuat guru semakin termotivasi dalam mengikuti kegiatan-kegiatan yang ditawarkan oleh MGMP yang ada di MAN Mamuju. Ada banyak kemudahan-kemudahan yang bisa diperoleh dalam kegiatan MGMP, disamping dapat menambah 
wawasan intelektualnya juga keikutsertaan dalam kegiatan MGMP dapat dijadikan angka kredit dalam kenaikan pangkat atau jabatan.

\section{Semangat}

Tingkat kehadiran dalam setiap kegiatan yang dilaksanakan MGMP MAN Mamuju menunjukkan hal yang sangat antusias. Hampir semua guru yang tergabung dalam MGMP selalu menghadiri kegiatan yang dilaksanakan oleh MGMP MAN Mamuju.

Para anggota MGMP sangat menyadari akan pentingnya setiap pertemuan yang dilaksanakan oleh setiap rumpun MGMP, sehingga mereka berupaya sedapat mungkin untuk selalu hadir pada acara pertemuan yang dilaksanakan karena hal ini demi untuk peningkatan wawasan agar tidak ketinggalan informasi. Bahkan mungkin saking bersemangatnya dalam mengikuti kegiatan-kegiatan MGMP ada beberapa guru yang rela mengikuti kegiatan yang dilaksanakan oleh rumpun MGMP yang bukan bidang studi yang ditekuninya selama ini.

\section{Efektivitas MGMP Dalam Meningkatkan Profesionalisme dan Kompetensi Guru}

Guru mempunyai peran vital dalam upaya memajukan mutu pendidikan. Perlu perhatian khusus dari pemerintah kepada mereka dalam meningkatkan kualifikasi. Untuk itulah, sejak tahun lalu Pihak Departemen Agama dalam hal ini Dirjen Mapenda Depag RI dan Lembaga Penjamin Mutu Pendidikan (LPMP) Provinsi Sulawesi Barat telah mengucurkan dana yang diperuntukan bagi kepada Madrasah Aliyah Negeri Mamuju (MAN Mamuju) untuk membentuk kelompok Musyawarah Guru Muatan Pelajaran Rumpun Madrasah (MGMP MAN Mamuju). Sehingga pada tahun 2007 yang lalu telah terbentuk beberapa rumpun MGMP di Madrasah Aliyah Negeri Mamuju diantaranya MGMP rumpun PAI, MGMP rumpun MIPA, MGMP rumpun IPS dan MGMP Bahasa Inggris se Madrasah Aliyah Mamuju.

Rumpun MGMP MAN Mamuju, merupakan kumpulan guru-guru yang ada di Madrasah Aliyah Negeri Mamuju dikumpulkan menjadi satu kelompok rumpun mata pelajaran yang di internal madrasah untuk membahas dan mendiskusikan atau melakukan pertemuan maupun pelatihan dalam upaya meningkatkan mutu dan kualifikasi para guru di masing-masing rumpun MGMP MAN Mamuju.

Musyawarah Guru Mata Pelajaran (MGMP) adalah salah satu organisasi pengembangan karier guru dan organisasi profesi sebagai tempat aktualisasi seorang guru terkhusus di Madrasah Aliyah Negeri Mamuju. Anggotanya meliputi antar 
guru mata pelajaran di lingkungan madrasah dan guru mata peiajaran yang berada pada Madrasah Aliyah Negeri Mamuju. Musyawarah Guru Mata Pelajaran (MGMP) juga sebagai suatu lembaga mandiri yang tidak mempunyai struktur organisasi, tetapi merupakan wadah berkumpulnya gum mata pelajaran sejenis, berperan melaksanakan pengembangan wawasan pengetahuan dan kompetensi guru sehingga memiliki dedikasi yang tinggi. Di samping itu, guru juga dapat melakukan refleksi dalam wadah MGMP kearah pembentukan profil guru yang professional.

Sebenarnya MGMP di Madrasah Aliyah Negeri Mamuju sudah terbentuk sebelum terbentuknya Kanwil Depag Sulbar, hanya saja organisasi ini belum berjalan secara optimal, karena tidak mendapat dukungan dana dari Kanwil Provinsi Sulawesi Selatan waktu itu. Setelah terbentuknya Kanwil Depag Sulbar geliat MGMP MAN Mamuju kembali berdenyut karena sudah mendapatkan dana untuk melaksanakan kegiatannya. Olehnya itu dari pihak Kanwil dalam hal ini dari bidang pendidikan Islam dan pihak direktorat pendidikan madrasah senantiasa mengajukan dan mengalokasikan anggaran pertahun untuk pelaksanaan Musyawarah Guru Mata Pelajaran (MGMP) Pendidikan Agama Islam pada sekolah umum dan guru madrasah, namun dana yang dianggarkan masih terbatas.

MGMP yang terbentuk di Madrasah Aliyah Negeri Mamuju masih dalam tataran intern Madrasah artinya MGMP tersebut lebih terfokus pada lingkup madrasah dan belum menyentuh wilayah Kelompok Kerja Madrasah (KKM), kecuali untuk MGMP Bahasa Inggris organisasi ini sudah merangkul seluruh Madrasah Swasta yang ada di Kabupaten Mamuju, sehingga kegiatan-kegiatan yang dilakukan senantiasa melibatkan seluruh guru-guru Bahasa Inggris yang ada di madrasah-madarah aliyah swasta se-Kabupaten Mamuju.

Untuk mengukur efektifitas dari setiap kegiatan yang dilakukan oleh masingmasing rumpun MGMP yang ada di MAN Mamuju tentunya merujuk pada sejauhmana manfaat dan peningkatan profesionalisme guru yang sebagai anggota dari MGMP dalam memberikan kontribusi positif terhadap minat, semangat dan motivasi guru setelah mengikuti pelatihan di organisasi MGMP.

Selama ini menurut penuturan para pengurus MGMP yang diwawancarai mengatakan bahwa animo para anggota MGMP di MAN Mamuju menunjukkan tingkat minat, semangat dan motivasi para guru sangat tinggi hal ini dibuktikan dari persentase kehadiran di setiap kegiatan yang dilakukan oleh masing-masing rumpun MGMP MAN Mamuju sangat memuaskan walaupun banyak kendalakendala yang dihadapi, setidaknya sudah berupaya untuk selalu hadir dan mengikuti setiap kegiatan atau pertemuan tersebut. 


\section{Amiruddin}

MGMP MAN Mamuj u telah melaksanakan beberapa kegiatan untuk peningkatan kompetensi dan profesionalisme gum seperti, workshop sosialisasi KTSPdan pembuatan perangkat pembelajaran, teknik pembuatan LKS, dan sosialisasi sertifikasi gum. Di samping itu dilakukan pula kegiatan berupa Teknik Pembuatan RPP, Metode Pembelajaran, Evaluasi Pembelajaran dan Pembuatan Silabus, Penetapan KKM7 SKBM serta Sistem Penilaian. Dari kegiatan ini tentunya memberikan pengaruh yang signifikan terhadap peningkatan SDM dan Profesionalisme bagi setiap anggota MGMP MAN Mamuju. Materi-materi yang telah diperoleh dari kegiatan MGMP MAN Mamuju dapat diaplikasikan dalam bentuk bagaimana cara membuat silabus yang baik, teknik pembuatan RPP, metode pembelajaran serta tahu dan mengerti memberikan evaluasi pembelajaran serta teknik penilaian.

Kegiatan MGMP MAN Mamuju sangat dirasakan manfaatnya dalam meningkatkan penguasaan dan pemahaman gum terhadap metode dan tata cara pengembangan silabus yang didalamnya tercakup beberapa aspek pengem-bangan tentang bagaimana penjabaran standar kompetensi dan kompetensi dasar yang di berikan dalam meteri pokok sehingga anak didik dapat dengan mudah memahami dan mencemanya, begitu pula dengan prinsip-prinsip pengembangan silabus yang hams berdasarkan pada beberapa indikator seperti, hams bersifat ilmiah, relevan, sistematis, konsisten, memadai, aktual dan konstektual, serta fleksibel dan menyeluruh.

Menurut Muh. Dinar Faisal, S.Ag, Kepala Seksi Madrasah pada Bidang Pendidikan Islam Kanwil Depag Sulbarbahwa, MGMP adalah sebuah lembaga musyawarah yang memusyawarahkan tentang sistem pembelajaran pada satu mata pelajaran seperti misalnya mata pelajaran Bahasa Arab mereka merembukkan didalam merumuskan KTSP, bagaimana sistim yang sesuai dengan kondisi daerah dengan memberlakukan kurikulum tingkat satuan pelajaran. Sehingga dengan demikian itu adalah sebuah forum atau lembaga musyawarah gum khusus bidang studi tertentu dan orientasinya disamping untuk meningkatkan SDM juga untuk meningkatkan kompetensi pembelajaran pada satuan pendidikan artinya bagaimana meningkatkan kompetensi pembelajaran itu dengan menggunakan kurikulum KTSP.

\section{PENUTUP}

\section{Kesimpulan}

Musyawarah Guru Mata Pelajaran (MGMP) MAN Mamuju adalah MGMP Rumpun Mata Pelajaran yang berlaku hanya di intern MAN Mamuju saja seperti: MGMP Rumpun PAI yang mencakup bidang studi Qur'an Hadits, Aqidah 
Akhlak, Fiqih, SKI, dan Mulok (Baca Tulis Al-Qur'an). MGMP Rumpun IPS yang terdiri dari beberapa bidang studi seperti, Ekonomi, Geografi, Sosiologi, Sejarah, dan PPKN. MGMP Rumpun MIPA yang meliputi bidang studi Biologi, Fisika, Kimia, Matematika. Dan terdapat satu MGMP yang merangkul seluruh Madrasah Aliyah se-Kabupaten Mamuju yaitu MGMP Bahasa Inggris.

Untuk meningkatkan mutu pendidikan di Madarasah Aliyah Negeri Mamuju telah ditempuh dengan jalan mengaktifkan kegiatan MGMP agar tercipta peningkatan wawasan dan pengetahuan kearah yang lebih professional. Kegiatankegiatan yang telah dilakukan oleh setiap Rumpun MGMP di MAN Mamuju cukup efektif hal ini terlihat dari tingkat pemahaman guru dalam pembuatana Silabus, Pembuatan LKS, RPP, KKM/SKBM, Program Tahunan, Program Semester, Analisis Hari Efektif sudah bisa diterapkan oleh guru sehingga betul-betul mamfaatnya dirasakan langsung oleh guru yang bersangkutan.

\section{Rekomendasi}

Untuk lebih mengefektikkan kegiatan MGMP di Madarasah Aliyah perlu adanya sokongan dana dari instansi terkait yaitu Departemen Agama dan Departemen Pendidikan Nasional dalam bentuk block grant agar lebih diproritaskan pada Madrasah Aliyah daripada Sekolah Umum yang sudah lebih maju dalam kegiatan MGMP. Sehingga kegiatan MGMP di Madrasah Aliyah bisa tetap intens dengan variasi kegiatan yang lebih banyak. Block grant diharapkan dapat memberdayakan MGMP dalam upaya meningkatkan mutu guru melalui kegiatan internal MGMP, diantaranya dalam hal; penyusunan silabus sesuai dengan standar isi dan standar kompetensi lulusan, pengembangan metode, pengembangan bahan ajar, pengembangan media, pengembangan alat peraga, pengembangan evaluasi, pengembangan profesi, serta peningkatan kesejahteraan dan perlindungan profesi guru. $\mathrm{F}^{*}$ ]

Catatan Akhir:

Penulis adalah peneliti Balai Penelitian dan Pengembangan Agama Makassar.

${ }^{2}$ Qowa' id dkk., 2003. Profit Guru Pendidikan Agama di Sekolah Umum, Jakarta: Puslitbang Pendidikan Agama dan Keagamaan Badan Litbang Agama dan Diklat Keagamaan.h.98

${ }^{3}$ Suhertian Plet, dkk. 1990. Supervisi Pendidikan dalam Rangka Rogram Inservice Education, Jakarta: Rieneka Cipta.h.6

${ }^{4}$ Djamarah dkk, 1994. Prestasi dan Kompetensi Guru, Surabaya : Usaha Nasional.h.34

Ibid.h.6 
Amiruddin

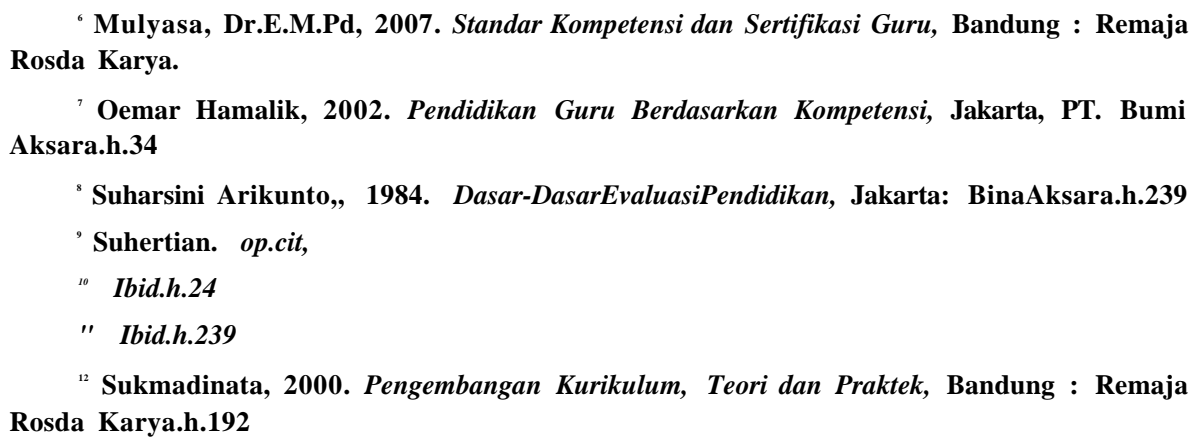

${ }^{-}$Mulyasa, Dr.E.M.Pd, 2007. Standar Kompetensi dan Sertifikasi Guru, Bandung : Remaja Rosda Karya.

' Oemar Hamalik, 2002. Pendidikan Guru Berdasarkan Kompetensi, Jakarta, PT. Bumi Aksara.h.34

${ }^{8}$ Suharsini Arikunto,, 1984. Dasar-DasarEvaluasiPendidikan, Jakarta: BinaAksara.h.239

Suhertian. op.cit,

10 Ibid.h.24

" Ibid.h.239

${ }^{12}$ Sukmadinata, 2000. Pengembangan Kurikulum, Teori dan Praktek, Bandung : Remaja Rosda Karya.h.192

\section{DAFTAR PUSTAKA}

Arikunto, Suharsini, 1984. Dasar-Dasar Evaluasi Pendidikan, Jakarta : Bina Aksara.

BPS Kabupaten Mamuju, 2007. Kabupaten Maтuju Dalam Angka 2007.

Departemen Pendidikan dan Kebudayaan, 1983. Alat Penelitian Kemampuan Guru, Program Ala V-B, Komponen Dasar Kependidikan. Dirjen Dikti.

Djamarah dkk, 1994. Prestasi dan Kompetensi Guru, Surabaya : Usaha Nasional.

Hamalik, Oemar, 2002. Pendidikan Guru Berdasarkan Kompetensi, Jakarta, PT. Bumi Aksara.

Mulyasa, Dr.E.M.Pd, 2007. Standar Kompetensi dan Sertifikasi Guru, Bandung : Remaja Rosda Karya.

Qowa'id dkk., 2003. Profil Guru Pendidikan Agama di Sekolah Umum, Jakarta : Puslitbang Pendidikan Agama dan Keagamaan Badan Litbang Agama dan Diklat Keagamaan.

Suhertin Plet, dkk, 1990, Supervisi Pendidikan dalam Rangka Rogram Inservice Education, Jakarta : Rieneka Cipta.

Sukmadinata, 2000. Pengembangan Kurikulum, Teori dan Praktek, Bandung: Remaja Rosda Karya. 